American Journal of Pharmaceutical Education 2020; 84 (3) Article 7689.

\title{
BRIEF
}

\section{The Impact of Pharmacy Student Participation in the White Coat Ceremony on Professionalization}

\author{
Laurie L. Briceland, PharmD, Jeffrey M. Brewer, PharmD, Angela Dominelli, PhD \\ Albany College of Pharmacy and Health Sciences, Albany, New York
}

Submitted May 20, 2019; accepted September 26, 2019; published March 2020.

Objective. To assess the impact of participation in a formal white coat ceremony on Doctor of Pharmacy (PharmD) students' professionalization by analyzing students' reflective writing.

Methods. First-year PharmD students participated in the college's white coat ceremony following orientation. During the Foundations of Pharmacy course in the first semester, students were instructed to reflect on and write about the impact the white coat ceremony had on them as a graded assignment. A grading rubric was developed to standardize assessment of the reflections and to differentiate critical reflection (which cites future behavioral change) from other forms of reflection that are less impactful, such as non-critical reflection, general understanding, and non-reflection. Thematic analysis was conducted and prevalent themes were identified. Each reflection was then reviewed to identify up to three themes.

Results. Of the 225 students in the incoming class of 2020, 218 submitted valid reflection assignments. Of these, $92 \%$ met critical reflection criteria. Four percent offered "negative connotation," while 75\% described an eye-opening experience or realization. Of 483 thematic classifications, six student professionalization themes were identified, as follows: personal achievement (26\%), professionalism $(21 \%)$, welcome to pharmacy (18\%), patient care $(16.8 \%)$, life-long learning $(12.8 \%)$, and code of ethics $(5.2 \%)$.

Conclusion. For the majority of PharmD students, the white coat ceremony held during first-year orientation had a positive impact on their professionalization. All pharmacy schools should conduct a white coat ceremony that includes recitation of the Pledge of Professionalism as an impactful first step toward student professionalization.

Keywords: reflective writing, reflective practitioner, white coat ceremony, student professional development, professional identity formation

\section{INTRODUCTION}

The importance of fostering professionalism in student pharmacists early in their academic career cannot be overstated. Academic researchers recommend that schools and colleges of pharmacy launch the topic of professional socialization on day one, and longitudinally nurture professionalization in students throughout the professional degree program. ${ }^{1-8}$ An oft-cited component of the first professional year (P1) is the white coat ceremony, which serves as a well-established symbolic rite of passage for students entering the pharmacy profession. ${ }^{9-13}$ The white coat ceremony, often culminating with students recitation of the Pledge of Professionalism, serves to initiate the process of student professionalization. 2,9

Corresponding Author: Laurie L. Briceland, Albany College of Pharmacy and Health Sciences, Albany, NY 12208. Tel: 518-694-7272. Email: laurie.briceland@acphs.edu.
The literature regarding the white coat ceremony has typically focused on the content, prevalence, and placement of the ceremony within the professional curriculum, and notably has not specifically assessed the impact of this ceremony on pharmacy students' professional development. ${ }^{10,14,15}$ An analysis of medical school white coat ceremonies suggested that future studies should focus on the students' appreciation and understanding of the messages presented to them during the ceremony. ${ }^{16}$

One method of assessing the impact of a curricular or co-curricular activity or event such as the white coat ceremony is through critical reflection, a contemplative critique of one's skills, performance, participation, and/or behaviors, as espoused by the Accreditation Council for Pharmacy Education (ACPE) Standard 4.1 (self-awareness): "the graduate is able to examine and reflect on personal knowledge, skills, abilities, beliefs, biases, motivations, and emotions that could enhance or limit personal and 


\section{American Journal of Pharmaceutical Education 2020; 84 (3) Article 7689.}

professional growth." ${ }^{17}$ The merits of incorporating reflective writing into pharmacy curricula as an enabling vehicle for students to use to clarify the impact of various experiences and document their learning have been well described in the literature. Indeed, reflective writing skills foster self-directed, life-long professional development and, ultimately, achievement of the goal of becoming a reflective practitioner. ${ }^{18-22}$ The art of reflection requires the learner to apply critical thought, and therefore is not reflexive in nature but rather a skill to be honed. Thus, incorporating reflective writing early in the pharmacy curriculum provides students the opportunity to begin honing this skill. ${ }^{23}$ Critical reflection involves more than an intellectual evaluation of an experience. It also recognizes the experience as an emotional and creative reframing and a springboard for future learning, and can culminate in behavioral transformation and heightened commitment. $^{24}$

The aim of this study was to assess the impact of the white coat ceremony on foundational professionalization of P1 pharmacy students through incorporation and analysis of critical reflective writing. Through this study we hoped to answer some of the following questions: What is the immediate significance of the white coat ceremony to student participants? What is the professional socialization impact of the white coat ceremony on student participants? What lasting impressions, if any, are made on students? Might these impressions serve as the foundation of the development of the student's professional identity throughout the remainder of the pharmacy curriculum and beyond?

\section{METHODS}

Two hundred twenty-five P1 students across two campuses participated in the college's white coat ceremony in 2016 at the conclusion of orientation and just prior to the beginning of classes. The white coat ceremony is a 20-year tradition at Albany College of Pharmacy and Health Sciences. The typical elements incorporated into the ceremony are listed in Appendix 1.

In the Foundations of Pharmacy course in the first year, students received instruction on the theory, practice, and value of critical reflection to the profession of pharmacy and the importance of adopting this practice early in their pharmacy career. ${ }^{18,19}$ Thus, a written reflection was the first graded assignment in the required Foundations of Pharmacy course and was to be included in the student's professional e-portfolio. For the assignment, students were instructed to critically reflect on the impact of participation in the white coat ceremony and given the following guidelines: "In $\leq 300$ words, describe how the White Coat Ceremony (WCC) made a meaningful impact on you, either negatively or positively, and how you will apply/change your future behaviors due to what you learned/experienced at the WCC as you embark on your journey as a student pharmacist/pharmacist."

A grading rubric was developed to standardize assessment of the white coat ceremony reflections. Specifically, the submissions were assessed to discern students' levels of reflection or non-reflection (Appendix 2 ). The course coordinator graded all of the reflections and subsequently created a word cloud based on the common themes that had emerged. Thereafter, using an iterative process of thematic analysis, each of the authors read an assigned third of the reflections to identify the most common themes and then added pertinent, correlated subthemes that emerged. This process culminated in identification of the following six key reflection themes: Professionalism; Welcome to Pharmacy; Personal Achievement; Life-Long Learning; Patient Care; and Code of Ethics. Correlated subthemes that were included within the six themes are included in Table 1.

Many of the submissions included wording that reflected more than one of the six identified themes. To determine the relative prevalence of each theme, each author independently assessed one-third of the reflections, and classified at least one and as many as three key themes per reflection. Additionally, each reflection was assessed for "negative connotation" (ie, predominately negative comments, such as that the white coat ceremony was "silly" or a "waste of time"), or "eye-opening experience" (eg, the student originally thought the white coat ceremony would be a waste of time, but was now struck by its impact, professional transformation, or linkage to all those who came before).

From student reflections, illustrative quotes that best represented each of the six thematic categories were selected based on two criteria: the quote demonstrated an "appreciation and understanding of messages,"16 as this attribute was noted to be lacking in the literature; and the quote highlighted an emotional/creative reframing of the topic by the student, that culminated in a behavioral transformation and heightened commitment, as evidence of critical reflection. ${ }^{24}$ Once the illustrative quotes were identified, one of the authors used an iterative process to select a group of quotes for each category that best represented the two criteria and the diversity of thought within the cohort.

\section{RESULTS}

Of the 225 students of the class of 2020 enrolled in the Foundations of Pharmacy course, 218 submitted valid reflection assignments regarding the white coat ceremony. All 218 met the criteria for reflection, with $92 \%$ 
American Journal of Pharmaceutical Education 2020; 84 (3) Article 7689.

Table 1. Thematic Analysis of First-Year Doctor of Pharmacy Students' Reflections on a White Coat Ceremony to Identify Elements of Professionalization Development $(\mathrm{N}=219)$

\begin{tabular}{|c|c|c|c|}
\hline Theme & $\begin{array}{l}\text { Students Whose } \\
\text { Reflections } \\
\text { Expressed } \\
\text { This Theme, No. (\%) }\end{array}$ & Subtheme & $\begin{array}{c}\text { Illustrative Quote From a Student } \\
\text { Reflection }\end{array}$ \\
\hline Professionalism & $103(21.3)$ & $\begin{array}{l}\text { Pledge of professionalism, lifetime of } \\
\text { service to others and/or to the } \\
\text { community, symbolism/tradition/ } \\
\text { cloaking }\end{array}$ & $\begin{array}{l}\text { The coats were more than cloth that we } \\
\text { will don throughout the next four } \\
\text { years. They, along with the individuals } \\
\text { who coated us, stand for } \\
\text { professionalism, integrity, and service } \\
\text { to others.. .Overall, the white coat } \\
\text { ceremony provided us with genuine } \\
\text { insight into what is expected of us, and } \\
\text { what we should expect of ourselves, as } \\
\text { part of becoming the next generation } \\
\text { of pharmacists. }\end{array}$ \\
\hline $\begin{array}{l}\text { Welcome to } \\
\text { Pharmacy }\end{array}$ & 85 (17.6) & $\begin{array}{l}\text { Welcome to the pharmacy profession, } \\
\text { rite of passage, Student Pharmacist, } \\
\text { presence/influence of faculty }\end{array}$ & $\begin{array}{l}\text { I felt a sense of intense pride that I chose } \\
\text { this career path and am now one step } \\
\text { closer to receiving my pharmacy } \\
\text { degree in a profession that will be ever- } \\
\text { changing and offers great opportunities. }\end{array}$ \\
\hline $\begin{array}{l}\text { Personal } \\
\text { Achievement }\end{array}$ & $127(26.3)$ & $\begin{array}{l}\text { Milestone, recognition, ceremony, pride, } \\
\text { journey to graduation, validation of } \\
\text { hard work to date, standard of } \\
\text { excellence }\end{array}$ & $\begin{array}{l}\text { The White Coat Ceremony was a } \\
\text { significant moment in my life that I } \\
\text { worked so hard for, and importantly it } \\
\text { begins a new chapter as a student } \\
\text { pharmacist, soon-to-be pharmacist } \\
\text { intern, and eventually a registered } \\
\text { pharmacist determined to save and } \\
\text { change lives. }\end{array}$ \\
\hline Lifelong Learning & $62(12.8)$ & $\begin{array}{l}\text { Realization of importance of self- } \\
\text { directed life-long learning, motivation } \\
\text { to learn, dedication to profession/ } \\
\text { career, passion for profession, plethora } \\
\text { of careers/opportunities in pharmacy }\end{array}$ & $\begin{array}{l}\text { I like the idea of how even after I } \\
\text { graduate, I am still a student. Even } \\
\text { when I am a working pharmacist, I will } \\
\text { never stop learning new things. As a } \\
\text { professional, I must continue to gain } \\
\text { knowledge in order to achieve } \\
\text { excellence in my field. }\end{array}$ \\
\hline Patient Care & $81(16.8)$ & $\begin{array}{l}\text { Patient welfare, health and wellness, } \\
\text { team-based/collaborative care, patient } \\
\text { advocacy and safety }\end{array}$ & $\begin{array}{l}\text { This is important because patients will } \\
\text { have a certain trust in me when I advise } \\
\text { on medications... After reciting this } \\
\text { Pledge, I thought to myself that, from } \\
\text { now on, I was learning for the patient, } \\
\text { not just for the grade. }\end{array}$ \\
\hline Code of Ethics & $25(5.2)$ & $\begin{array}{l}\text { Do what is right when no one is looking, } \\
\text { responsibility, integrity }\end{array}$ & $\begin{array}{l}\text { By accepting the coat and reciting the } \\
\text { Pledge of Professionalism, I have } \\
\text { made a commitment not simply to } \\
\text { finish pharmacy school and become a } \\
\text { pharmacist. I commit to all those who } \\
\text { have worn the coat before me; I now } \\
\text { have a responsibility to uphold the } \\
\text { knowledge, service, and dignity that it } \\
\text { represents...This was a very profound } \\
\text { realization for me, and I look forward } \\
\text { to the challenge of living up to the } \\
\text { commitments that I have made. }\end{array}$ \\
\hline
\end{tabular}




\section{American Journal of Pharmaceutical Education 2020; 84 (3) Article 7689.}

reaching critical reflection, indicating that they included a reference to changing future behavior. The thematic classifications that students reflected upon, along with illustrative quotes, are presented in Table 1. Of 483 thematic classifications, the most prevalent in the reflections were Personal Achievement (26\%), Professionalism (21\%), and Welcome to Pharmacy (18\%). Four percent of the students offered "negative connotation" in their reflection about the white coat ceremony, and $75 \%$ described having an "eye-opening" experience/realization.

\section{DISCUSSION}

White coat ceremonies are becoming increasingly commonplace in schools of pharmacy and serve as a rite of passage into the profession. ${ }^{2,9,14,15}$ To date, there is a paucity of data in the literature describing the professionalization impact of the white coat ceremony on participating students. Using critical reflective writing as our assessment tool, we captured students' perceptions, which expressed the impact on their professionalization as a direct result of participation in the white coat ceremony (Table 1).

The American Association of Colleges of Pharmacy Council of Deans Task Force report on Professional Identity Formation defined it as the "transformative process of identifying and internalizing the ways of being and relating within a professional role." This task force deemed that 10 traits or factors played a key role in this socialization, including knowledge and skills of the profession; commitment to self-improvement of skills and knowledge; service orientation; pride in the profession; covenantal relationship with the client; creativity and innovation; conscience and trustworthiness; accountability for one's work; ethical decision-making; and leadership. ${ }^{25}$ Interestingly, our students reflected on all 10 of these traits, with varying degrees of emphasis, as per our distillation of reflection content into six overarching themes. While we recognize that the white coat ceremony is one small component of student professional development, ${ }^{26}$ our findings suggest that participation in the white coat ceremony serves as a powerful way to introduce student professionalization early in the professional education journey, with many important professional themes surfacing as revealed by our thematic analysis.

Perhaps not unexpectedly, the most prevalent theme in students' reflections was "personal achievement" (26\%). This could be attributed to the fact that many families were in attendance at the white coat ceremony, showering the students with support and accolades, with celebrations often including photos, flowers, and dinner. Thus, when students were asked to reflect upon the impact of the white coat ceremony, their first thought was of the pride that they and their families felt for achieving this "entry into the profession" milestone and validation of the student's hard work to date.

The next two most prevalent themes identified in student reflections were "professionalism" $(21.3 \%)$ and "welcome to pharmacy" (17.6\%). Reciting the Pledge of Professionalism along with their classmates proved to be a frequently cited powerful means of professionalization, and as such we would recommend that other schools insert this pledge into their the white coat ceremony if they do not already do so. Students also recognized that the white coat cloaking was much more than receiving a new and integral piece of their professional wardrobe, but rather the coat was deeply symbolic of beginning a lifetime of service to the profession, as was mentioned by many of the speakers during the ceremony. The actual cloaking by a faculty member who was also wearing a white coat represented to students that these faculty members, who often were cited by name in reflections, were professional role models to the students. Such positive role modeling is essential to the development of strong professional identities, ${ }^{26}$ and the white coat ceremony served as foundational in this regard. Further, students viewed the cloaking faculty members as gatekeepers to the profession of pharmacy, and these gatekeepers were now welcoming them in. This realization proved to leave an indelible mark on many students, as reflected in their writing.

Close to $17 \%$ of students reflected that the white coat ceremony emphasized several aspects of patient care, including collaborative practice, patient safety, and patient advocacy. Importantly, the covenantal relationship between patient and pharmacist, a basic tenet at the heart of development of student professionalism, ${ }^{27}$ was mentioned by speakers during the white coat ceremony and proved to positively impact students as evidenced in their reflections. Also, a small percentage (5.2\%) of students commented on the ethical responsibilities inherent in becoming a pharmacy professional, citing verbatim what one of the speakers (JMB) had stated during the white coat ceremony: "do what is right when no one is looking."

Students also came to realize the importance of selfdirected life-long learning, as evidenced in $12.8 \%$ of reflections. The white coat ceremony motivated students to dedicate themselves to their current studies and to their profession, with many stating that they wished to become involved in professional organizations, to innovate, and to become the best pharmacist possible. Students recognized through speaker presentations during the white coat ceremony that there are a plethora of careers and professional opportunities in the pharmacy field, and many students 


\section{American Journal of Pharmaceutical Education 2020; 84 (3) Article 7689.}

were enthused about embracing the many co-curricular and curricular learning opportunities ahead of them.

Our analysis is not without limitations. First, the reflection was part of a graded assignment and the student's name was attached, raising the possibility that the reflections may have been different if they had been submitted anonymously. We also did not study the age or prior work experience of the students, and thus could not evaluate whether age or work experience, or perhaps other demography predicted certain themes identified in the reflections. While we did not specifically prompt students to indicate whether participation in the white coat ceremony was an overall positive "eye-opening" experience or an overall negative experience, we did prompt them to describe how participation in the ceremony impacted them, either negatively or positively. For the 4\% who expressed "negative connotations," representative comments centered around student dislike of having to attend a formal ceremony (similar to those who choose not to attend a graduation ceremony), or dislike because their parents lived far away and could not witness the ceremony; student stating they do not need a white coat to prove that the student is a professional; or inconvenient scheduling of the ceremony, etc. Thus, we expected some negative comments and believe that some of these students, as they develop their own professional identity over time, may grow to understand the importance of the white coat ceremony. On the flip side, $96 \%$ of students in the collective who did not offer negative comment recognized that white coat ceremony participation was a meaningful introduction to student professionalization, as evidenced in the six themes that emerged from their reflections.

Based on our analysis of students' reflections on the impact of participation in the white coat ceremony we have validated that participation does result in student professionalization and is perhaps the initiation of this process given the placement of most white coat ceremonies during orientation in the first year. Having this knowledge, the College will approach the next white coat ceremony cognizant of the fact that the ceremony will be deeply meaningful to the vast majority of our students. While most pharmacy schools already conduct a white coat ceremony, we encourage those that may not to consider adding it to their orientation program. We also suggest that the ceremony include recitation of the Pledge of Professionalism as we have found this to be an impactful method of student professionalization.

\section{CONCLUSION}

For the majority of first-year pharmacy students in this cohort, the white coat ceremony is an "eye-opening" experience that has positive impacts on several desired aspects of student professionalization. Our thematic analysis of the impact of participation in the white coat ceremony on students' professional development serves to validate the important professionalization aspects of the ceremony. With each future white coat ceremony that we (and other colleges of pharmacy) hold, we will know that students are truly gaining a meaningful professionalization experience.

\section{REFERENCES}

1. Mylrea MF, Gupta TS, Glass BD. Professionalization in pharmacy education as a matter of identity. Am J Pharm Educ. 2015;79.9:1-9. 2. APhA-ASP/AACP-COD Task Force on Professionalism. White Paper on Pharmacy Student Professionalism. J Am Pharm Assoc. 2000;40:96-102.

3. Poirier TI, Gupchup GV. Assessment of pharmacy student professionalism across a curriculum. Am J Pharm Educ. 2010;74(4):Article 62.

4. Hammer DP. Professional attitudes and behaviors: the "A's and B's" of professionalism. Am J Pharm Educ. 2000;64(4):455-464.

5. Cruess RL. Teaching professionalism: theory, principles, and practices. Clin Orthop Relat Res. 2006;449:177-185.

6. Noble C, O'Brien M, Coombes I, Shaw PN, Nissen L, Clavarino A. Becoming a pharmacist: students' perceptions of their curricular experience and professional identity formation. Curr Pharm Teach Learn. 2014;(6):327-339.

7. Schafheutle EI, Hassell K, Ashcroft DA, Hall J, Harrison S. How do pharmacy students learn professionalism? Int J Pharm Prac. 2012;20:118-128.

8. Welch B, Spooner JJ, Tanzer K, Dintzner MR. Design and implementation of a professional development course series. Am J Pharm Educ. 2017;81(10):Article 6394.

9. Berger BA, Butler SL, Duncan-Hewitt W, et al. Changing the culture: an institution-wide approach to instilling professional values. Am J Pharm Educ. 2004;68.1-5:F1-F9.

10. Carter BL, Brunson BJ, Hatfield CL, Valuck RJ. Description of an introductory course designed to socialize pharmacy students. $\mathrm{Am} \mathrm{J}$ Pharm Educ. 2000;64.2:166.

11. Hammer DP, Berger BA, Beardsley RS, Easton MR. Student professionalism. Am J Pharm Educ. 2003;67. 1/4.:544-572.

12. Boyle CJ, Beardsley RS, Morgan JA, Rodriguez de Bittner M. Professionalism: a determining factor in experiential learning. Am J Pharm Educ. 2007;71(2):Article 31.

13. Holt SL, Lau MS, Wong FL. Tenets of professionalism for pharmacy students. Pharmacotherapy. 2009;29(6):757-759.

14. Brown DL, Ferrill MJ, Pankaskie MC. White coat ceremonies in US schools of pharmacy. Ann Pharmacother. 2003;37:1414-1419.

15. Sylvia LM. Enhancing professionalism of pharmacy students: results of a national survey. Am J Pharm Educ. 2004; 68(4):Article 104. 16. Karnieli-Miller O, Frankel RM, Inui T. Cloak of compassion, or evidence of elitism? an empirical analysis of white coat ceremonies. Med Educ. 2013;47:97-108.

17. Accreditation Council for Pharmacy Education. Accreditation standards and key elements for the professional program in pharmacy leading to the doctor of pharmacy degree. Standards 2016. https:// www.acpe-accredit.org/pdf/Standards2016FINAL.pdf. 18. Tsingos C, Bosnic-Anticevich S, Smith L. Reflective practice and its implications for pharmacy education. Am J Pharm Educ. 2014;78(1):Article 18. 


\section{American Journal of Pharmaceutical Education 2020; 84 (3) Article 7689.}

19. Tsingos-Lucas C, Bosnic-Anticevich S, Schneider CR, Smith L. The effect of reflective articles on reflective thinking ability in an undergraduate pharmacy curriculum. Am J Pharm Educ. 2016;80(4):65.

20. Boyd EM, Fales AW. Reflective learning: key to learning from experience. J Hum Psychol. 1983;23(2):99-117.

21. Brown B, Holt-Macey S, Martin B, Skau K, Vogt E. Developing the reflective practitioner: what, so what, now what. Curr Pharm Teach Learn. 2015;7:705-715.

22. Strang AF, Briceland LL, Garrison G, Kane TH, Brewer JM, Seo $\mathrm{S}$. Are students practicing self-awareness? An inventory of critical reflection throughout the curriculum/co-curriculum. 2018 AACP Annual Meeting Abstract. 119th Annual Meeting of the American Association of Colleges of Pharmacy, Boston, Massachusetts, July 21-25, 2018. Am J Pharm Educ. 2018;82(5):Article 7158.
23. Bouldin A. Reflection is not reflexive. Am J Pharm Educ. 2017;81(9):Article 6832.

24. Branch WT. Teaching professional and humanistic values: suggestion for a practical and theoretical model. Patient Education and Counseling. 2015(98):162-167.

25. American Associate of Colleges of Pharmacy. Taskforce on professional identity formation - final report. 2014. https://connect.aacp.org/ HigherLogic/System/DownloadDocumentFile.ashx?DocumentFileKey= d305e1b5-9870-1eb5-307e-dd60ff7aac20\&forceDialog=0. Accessed April 29, 2019.

26. Noble C, McKauge L, Clavarino A. Pharmacy student professional identity formation: a scoping review. Integr Pharm Res Pract. 2019;8:15-34.

27. Roth MT, Zlatic TD. ACCP White Paper: Development of Student Professionalism. Pharmacotherapy 2009;29(6):749-756. 


\section{American Journal of Pharmaceutical Education 2020; 84 (3) Article 7689.}

\section{Appendix 1. Typical Elements Included in the White Coat Ceremony at ACPHS}

Formal procession to music of the P1 students into the venue where upper class students, faculty/staff and family are in attendance National anthem and welcoming remarks

Commentary on the history and significance of the white coat ceremony from Professional Affairs Director/Dean

Words of professional inspiration from the Dean/Dean's Office

Keynote Guest Speaker White Coat Address

White Coat Cloaking of small groups of students by panel of pharmacy faculty

P3 Student leader-led recitation of the Pledge of Professionalism, witnessed by faculty, speakers, family in attendance

Reception

\section{Appendix 2. Grading Rubric for White Coat Ceremony Reflective Writing Assignment (5-point scale)}

\begin{tabular}{|c|c|c|c|c|}
\hline Assessment & 3 (Critical Reflection) & 2 (Reflection) & 1 (Understanding) & 0 (Non-reflection) \\
\hline $\begin{array}{l}\text { Critical } \\
\text { Reflection }\end{array}$ & $\begin{array}{l}\text { Student provides sufficient } \\
\text { description and critical } \\
\text { analysis of participation } \\
\text { in the experience and } \\
\text { applies it to future } \\
\text { practice/behaviors. } \\
\text { Reflection is thorough, } \\
\text { thoughtful, detailed and } \\
\text { clear. }\end{array}$ & $\begin{array}{l}\text { Student provides sufficient } \\
\text { description and analysis } \\
\text { of participation of the } \\
\text { experience but DOES } \\
\text { NOT apply it to future } \\
\text { practice/behaviors. }\end{array}$ & $\begin{array}{l}\text { Student mentions in } \\
\text { general the importance } \\
\text { of WCC to future } \\
\text { practice, but provides } \\
\text { superficial summary or is } \\
\text { lacking description and } \\
\text { analysis of personal } \\
\text { WCC participation. }\end{array}$ & $\begin{array}{l}\text { Student provides a brief, } \\
\text { superficial, generalized } \\
\text { analysis of the WCC, } \\
\text { AND does not } \\
\text { adequately reflect on the } \\
\text { impact of the White Coat } \\
\text { Ceremony (or } \\
\text { Professionalism Pledge } \\
\text { if not at WCC); } \\
\text { reflection is incomplete } \\
\text { or unclear. }\end{array}$ \\
\hline $\begin{array}{c}\text { Spelling and } \\
\text { Grammar }\end{array}$ & & $\begin{array}{l}\text { No apparent spelling or } \\
\text { grammar errors. }\end{array}$ & $\begin{array}{l}\text { No more than } 3 \text { spelling } \\
\text { and/or grammatical } \\
\text { errors. }\end{array}$ & $\begin{array}{l}\text { More than } 3 \text { spelling and/or } \\
\text { grammatical errors and/ } \\
\text { or }>300 \text { words. }\end{array}$ \\
\hline
\end{tabular}

